\title{
ABBREVIATIONS OF WORKS
}

BY JACQUES DERRIDA

Page references are given first to the original French, and then to published translations where these exist. I have very often made slight changes to published translations in the interests of consistency and accuracy.

AEL Adieu à Emmanuel Lévinas. Paris: Galilée, 1997. Adieu to Emmanuel Levinas. Trans. Pascale-Anne Brault and Michael Naas. Stanford: Stanford University Press, I999.

BS I Séminaire La bête et le souverain I (200I-2002). Paris: Galilée, 2008. The Beast and the Sovereign I. Trans. Geoffrey Bennington. Chicago: University of Chicago Press, 2009.

BS II Séminaire La bête et le souverain II (2002-2003). Paris: Galilée, 2010. The Beast and the Sovereign II. Trans. Geoffrey Bennington. Chicago: University of Chicago Press, 20II.

CFU Chaque fois unique, la fin du monde. Paris: Galilée, 2003. The Work of Mourning. Trans. Pascale-Anne Brault and Michael Naas. Chicago: University of Chicago Press, 200I.

DES De l'esprit: Heidegger et la question. Paris: Galilée, 1987. Of Spirit: Heidegger and the Question. Trans. Geoffrey Bennington and Rachel Bowlby. Chicago: University of Chicago Press, I99I.

D La dissémination. Paris: Seuil, I972. Dissemination. Trans. Barbara Johnson. Chicago: University of Chicago Press, 1981.

DP Du droit à la philosophie. Paris: Galilée, 1990. Who's Afraid of Philosophy? Right to Philosophy I, and Eyes of the University: Right to Philosophy 2. Trans. Jan Plug. Stanford: Stanford University Press, 2002, 2004 .

EAP Etats d'âme de la psychanalyse. Paris: Galilée, 2000. Trans. Peggy Kamuf as "Psychoanalysis Searches the States of Its Soul," in Jacques Derrida, Without Alibi. Stanford: Stanford University Press, 2002.

ED L'écriture et la difference. Paris: Seuil, 1967. Writing and Difference. Trans. Alan Bass. Chicago: University of Chicago Press, I98I. 
FC Feu la cendre. Paris: Des femmes, i987. Cinders. Trans. Ned Lukacher. Lincoln: University of Nebraska Press, I99ı.

FS "Foi et savoir: Les deux sources de la 'religion' aux limites de la simples raison." In La religion, ed. Jacques Derrida and Gianni Vattimo, 9-86. Paris: Seuil, 1996. Reprinted in Foi et savoir, suivi de Le siècle et le pardon, 7-Ioo. Paris: Seuil, 200I. "Faith and Knowledge: The Two Sources of 'Religion' at the Limits of Reason Alone." In Religion, ed. Jacques Derrida and Gianni Vattimo, trans. Samuel Weber. Stanford: Stanford University Press, I998.

G De la grammatologie. Paris: Minuit, I967. Of Grammatology. Trans. Gayatri Chakravorty Spivak. Baltimore: Johns Hopkins University Press, I976.

GIII Geschlecht III. Ed. Geoffrey Bennington, Katie Chenoweth, and Rodrigo Therezo. Paris: Seuil, 2or8. Trans. Katie Chenoweth and Rodrigo Therezo. Chicago: University of Chicago Press, 2020.

GL Glas. Paris: Galilée, I974. Clang. Trans. Geoffrey Bennington and David Wills. Minneapolis: University of Minnesota Press, 2020.

HC H.C. pour la vie, c'est-à-dire... Paris: Galilée, 2002. H.C. for Life, That Is to Say. . . Trans. Laurent Milesi and Stefan Herbrechter. Stanford: Stanford University Press, 2006.

HQE Heidegger: La question de l'être et l'histoire. Paris: Galilée, 2013. Heidegger: The Question of Being and History. Trans. Geoffrey Bennington. Chicago: University of Chicago Press, 2016.

LI Limited Inc. [I978]. Paris: Galilée, I990. Limited Inc. Trans. Jeffrey Mehlmann and Samuel Weber. Evanston, IL: Northwestern University Press, I988.

M Marges - de la philosophie. Paris: Minuit, I972. Margins of Philosophy. Trans. Alan Bass. Chicago: University of Chicago Press, I982.

MA Mal d'archive: Une impression freudienne. Paris: Galilée, I995. Archive Fever: A Freudian Impression. Trans. Eric Prenowitz. Chicago: University of Chicago Press, I996.

OTO Otobiographies: L'enseignement de Nietzsche et la politique du nom propre. Paris. Galilée, I984. Partial translation by Tom Keenan and Tom Pepper in Jacques Derrida, Negotiations: Interventions and Interviews, I97I-200I. Ed. Elizabeth Rottenberg. Stanford: Stanford University Press, 2002. 
PA Politiques de l'amitié. Paris: Galilée, 1994. The Politics of Friendship (partial translation). Trans. George Collins. London: Verso, I997.

PAS Passions: L'offrande oblique. Paris: Galilée, r993. "Passions: An Oblique Offering." In Derrida: A Critical Reader, ed. and trans. David Wood. Oxford: Blackwell, I992.

PG Le problème de la genèse dans la philosophie de Husserl. Paris: PUF, 1990. The Problem of Genesis in Husserl's Philosophy. Trans. Marian Hobson. Chicago: University of Chicago Press, 2003.

PM I Séminaire la peine de mort, Volume I (1999-200o). Paris: Galilée, 20I 2. The Death Penalty I. Trans. Peggy Kamuf. Chicago: University of Chicago Press, 20I4.

PM II Séminaire la peine de mort, Volume II (2000-200I). Paris: Galilée, 2015. The Death Penalty II. Trans. Elizabeth Rottenberg. Chicago: University of Chicago Press, 2017.

POS Positions. Paris: Minuit, 1972. Positions. Trans. Alan Bass et al. Chicago: University of Chicago Press, I98I.

PSY Psyché: Inventions de l'autre. Paris: Galilée, I987. Psyche: Inventions of the Other. 2 vols. Trans. Peggy Kamuf et al. Stanford: Stanford University Press, 2007.

RES Résistances de la psychanalyse. Paris: Galilée, I996. Trans. Peggy Kamuf, Pascale-Anne Brault, and Michael Naas as Resistances of Psychoanalysis. Stanford: Stanford University Press, 1998.

SM Spectres de Marx: L'état de la dette, le travail du deuil et la nouvelle Internationale. Paris: Galilée, 1993. Specters of Marx: The State of the Debt, the Work of Mourning, and the New International. Trans. Peggy Kamuf. New York: Routledge, I994.

TR “Qu'est-ce qu'une traduction 'relevante'?” in Cabier de l'Herne: Derrida (2004). "What Is a 'Relevant' Translation?" Trans. Lawrence Venuti. Critical Inquiry 27, no. 2 (200I): I74-200.

V Voyous: Deux essais sur la raison. Paris: Galilée, 2003. Rogues: Two Essays on Reason. Trans. Pascale-Anne Brault and Michael Naas. Stanford: Stanford University Press, 2005.

VEP La verité en peinture. Paris: Flammarion, I979. Trans. Geoffrey Bennington and Ian McLeod. Chicago: University of Chicago Press, 1987 . 

SCATTER 2 
